\title{
Lesbians Under National Socialism: Legal Indifference, Real Oppression
}

\author{
Hannah Elizabeth Crowder*
}

\begin{abstract}
Lesbian women experienced unique persecution under National Socialism in Germany despite no specific legal discrimination being placed upon them. Through strict expectations of gender norms, lesbian women experienced oppression leading up to the Second World War, and during the war were heavily targeted and arrested under a wide range of charges. When women didn't perform their gender roles to the standard expected of them they were socially ostracized, or directly targeted in some cases. The experiences of women in Ravensbrück concentration camp are used to illustrate the mistreatment and directed attacks on sexual minority women. Finally, the author ties together the treatment of women both before and during the war to show that lesbian women, while not persecuted through formal laws, experienced significant trauma under National Socialism through a variety of policies and practices, both social and political.
\end{abstract}

Keywords: lesbian; Nazi; national socialism; sexuality; oppression

Living in Nazi Germany as a lesbian was a challenge deserving of remembrance. While lesbian lives in Germany prior to the Second World War were for the most part open and safe, the rise of the National Socialist Party brought, along with war, a change in policies and public attitudes regarding homosexuality, and as a result many lesbian women faced persecution, oppression, and even incarceration. they, too, experienced challenges, and the lack of a legal framework for oppression should not negate the experiences of these women. For lesbians, the prevailing gender dichotomy caused significant problems, as they were seen as aberrations to the heteronormative Nazi ideal. The dual stigma of both sexuality and gender meant losing job security, forced assimilation into a patriarchal society, possible incarceration in concentration camps, and for some, even death. It is with a close focus on gender and gender norms under National Socialism that the supposed threat and very real persecution of lesbian women is best understood.

Germany was home to the largest openly homosexual population in the world under the Weimar republic, up until $1933 .^{1}$ Berlin alone had over 100 bars welcoming gay clientele, gender reassignment surgery was occurring in Berlin as early as 1930, and many periodicals for gay men and lesbian women were in wide circulation. ${ }^{2}$ For women in particular, large, organized groups of lesbians first appeared in Berlin in the mid 1920s. ${ }^{3}$ Paragraph 175, the German law prohibiting homosexual relations between men, was passed

1. Bob Cant, "'Anyone who thinks of homosexual love is our enemy' remembering the experiences of lesbian gay, bisexual and transgender people during the Nazi terror," Diversity and Equality in Health Care 9, 2012, 239.

2. Ibid.

3. Marti M. Lybeck, Desiring Emancipation: New Women and Homosexuality in Germany, 1890-1933. SUNY Press, New York, NY: 2014, 8.

*Department of History, College of Arts and Science, University of Saskatchewan, Saskatoon, SK, Canada

Correspondence: h.ecrowder@gmail.com 
in 1871 but was not strictly enforced, and men and women had relative freedom in their sexual expression. ${ }^{4}$

When Adolf Hitler and the National Socialist Party took control of the government in 1933, over a decade of freedom for lesbian women came to an abrupt halt. Their organizing efforts, emancipation, and visibility were stymied as their meeting places and publications were systematically shut down. ${ }^{5}$ Intimidation and arrests of homosexual individuals intensified, both with the expansion of Paragraph 175 to further criminalize gay men and with the public sanitization program leading up to the Olympics in $1936 .{ }^{6}$ Yet, a debate in 1936 over whether to further expand Paragraph 175 to include lesbians did not result in formal legalized discrimination against these women. The Nazis concluded that their "population policy was not sufficiently threatened by female sexuality," as women were more likely to continue engaging in "normal" sexual relations despite their "seduction" by homosexuality, and could still contribute to "population growth and development. ${ }^{\prime \prime}$

This ruling clearly shows the undercurrents of discrimination against women in general, and towards lesbians in particular. Women in Germany were expected to fulfill one purpose: to produce 'good' Aryan children and further propagate the Aryan nation through motherhood and service to their husbands. German propaganda campaigns encouraged women to abide by this doctrine, creating methods of punishment for those who did not conform. Lesbians faced consequences more often than other women as they tended to be furthest from the expected norm, remaining unmarried and childless more frequently than other women. ${ }^{8}$ Although they could not be criminally charged in the same way as gay men, lesbians "could be susceptible to persecution through the axis of gender, that is, through non-conformity to the norms of gender, including marriage and the institution of heterosexuality." ${ }^{\prime \prime}$

Maintaining strict gender roles was one of the core values of National Socialism, along with blood purity. Due to low population, the Nazis actively pushed their motherhood agenda onto all women, encouraging large families through financial stimulus programs and punishing women who remained unmarried or childless. This was reinforced in the official publication of the Schutzstaffel (SS) guard, Das Schwarze Korps, which said that "the true

4. Cant 2012, 239.

5. Lybeck 2014, 154.

6. Cant 2012, 239.

7. William J. Spurlin, Lost Intimacies: Rethinking Homosexuality under National Socialism, Peter Lang, New York, NY: 2009, 52.

8. Claudia Schoppmann, Days of Masquerade: Life Stories of Lesbians During the Third Reich, translated by Allison Brown, Columbia University Press, New York, NY: 1996, 12.

9. Spurlin 2009, 45, emphasis in original. woman" suffers if unmarried, "not because she lacks sexual intercourse, but because she lacks a child and has not answered her calling to motherhood. ${ }^{10}$ Other forms of femininity that were not appropriately portrayed by women could result in harassment or punishment, as well. Hilde Radusch, a young lesbian woman, lost her job when she refused to accept the sexual advances of her superior officer. ${ }^{11}$ This was a milder punishment; some women who rejected "the sexual advances of senior male military officers" were denounced as sexually abnormal and arrested for being asocial. ${ }^{12}$

Nonconforming lesbian women also became political enemies, "insofar as they challenged the gender/sexual politics of the Nazi state," which marked them doubly as targets of oppression. ${ }^{13}$ Further, while lesbian sexuality was not a formal crime that led to imprisonment, political 'enemies' were regularly arrested under the Nazi police state, leading to the imprisonment and incarceration of many lesbians in camps. Lesbians became categorized as "resistant women" who could create trouble for the Nazis. Despite this labelling, the Nazi party did not categorize lesbians the same was as other political criminals, as "what lesbians and many other women resisted was the Nazi enforcement of rigid gender norms, especially since...the Nazis saw women as reproductive rather than political beings. ${ }^{14}$ The crime here was not political affiliation or ideological resistance to National Socialism, but resistance to gender roles that lesbian women did not and could not adopt.

This is not to say that lesbian women did not try to assimilate. Perhaps one of the greatest ways in which these women suffered was through the loss of identity in their efforts to play the gender role imposed on them by the state. Many lesbians chose to "lead a psychologically draining double life" in an effort to correspond to Nazi ideals and avoid raising suspicions. ${ }^{15}$ The "survival mentality" of the 1930s-40s meant a lack of romantic involvement or meaningful relationships for many women, and some chose even to marry men - often gay men - to keep societal pressure at bay. ${ }^{16}$

Persecution for lesbians did not come from official sources alone, but from concerned members of their own communities. Despite the fact that lesbianism was not illegal, "women who drew negative attention because of their lesbianism ran a clear, pronounced risk of provoking

10. Das Schwarze Korps, Publication of the Schutzstaffeln, October 21, 1937, quoted in Schoppmann, 1996, 12.

11. Schoppmann, 1996, 33.

12. Spurlin, 2009, 53.

13. Ibid.

14. Ibid, 46 \& 54 .

15. Schoppmann 1996, 18.

16. Lybeck 2014, 184; Schoppmann 1996, 12. 
anxiety" which could lead to "state violence."17 Denunciations of lesbians by neighbours who reported them to the Gestapo did occur, and a handful of women were arrested as a result. ${ }^{18}$ While this number in no way compares to the 100,000 men taken in for questioning under Paragraph 175 between 1935 and 1945, it created an atmosphere of fear for lesbian women, pressuring many to disguise their identities. ${ }^{19}$ It is important to note that "not all women who had affairs with women transgressed gender norms." ${ }^{20}$ Rather, some women were able to maintain appearances of heteronormativity and avoid persecution throughout the war, but these were generally women in privileged positions. Presenting "norms of Aryan femininity" as protection and disguise was, "of course, not an option for women who were racially endangered, handicapped, or politically endangered. ${ }^{21}$

Although the Nazis asserted that women were not inherently political beings, a large number of both heterosexual and homosexual women engaged in resistance throughout the war. Such women were punished, for reasons other than, but in conjunction with, their sexual identities. Elisabeth Zimmerman is one example. She worked in the German office in Paris, hoping for more lenient treatment of her sexual orientation in a more liberal, yet occupied France. Zimmerman forged her boss's signature to get Jewish people fleeing persecution passes across the demarcation zone and into free France for three years, before losing her job over rumours of an affair with another German military woman. ${ }^{22}$ Rosa Jochmann was a communist women's leader in Austria and was brought to Ravensbrück Camp after organizing underground political rallies. ${ }^{23}$ Hilde Radush, mentioned earlier, set up illegal post office operations for those denied access to state facilities but was arrested in connection to the communist resistance, after which she led rallies in the women's prison for better living conditions. ${ }^{24}$ Hilde received warnings about her sexuality, but it was never listed as a reason for her numerous arrests; after the war, she wrote, "I never saw myself as a victim, but always as a fighter." ${ }^{25}$ These examples highlight a trend of challenging oppression and subsequent intensified persecution at the hands of the Nazis.

17. Laurie Marhoefer, "Lesbianism, Transvestitism, and the Nazi State: A Microhistory of a Gestapo Investigation, 1939-1943," American Historical Review 121:4. 2016, 1194.

18. Ibid, 1167.

19. Cant 2012, 239.

20. Marhoefer 2016, 1168.

21. Spurlin 2009, 56.

22. Schoppmann 1996, 116.

23. Sarah Helm, Ravensbrück: Life and Death in Hitler's Concentration Camp for Women, Penguin Random House, New York, NY: 2014, 138. 24. Schoppmann 1996, 33-37.

25. Ibid, 40.
For those women who were arrested and detained, the strict gender norms of the National Socialists dictated that they receive their punishment in spaces separate from men. Ravensbrück was the only Nazi concentration camp built exclusively for women, and it opened in 1939, four months before the outbreak of the war. ${ }^{26}$ Altogether, Ravensbrück saw 130,000 prisoners, about one third of which were in the asocial category, branded with the black triangle as a symbol of their 'crime'. ${ }^{27}$ This catch-all designation was used for "failure to live up to what the Nazis considered to be good citizenship and the fulfillment of one's social obligations." ${ }^{28}$ As lesbians did not attain the traditional female path of marriage and motherhood, they were often categorized as asocial, along with prostitutes, individuals with disabilities, women, the homeless, and occasionally, unwed mothers. ${ }^{29}$ These arrests had no judicial authorization and were allowed under the discretion of the police as a form of "protective custody. ${ }^{130}$ Radusch was held in protective custody for one of her arrests, and responded smartly: "you have to protect the state from us." ${ }^{13}$

The purpose of Ravensbrück was to eradicate those women who posed a threat to societal values, such as lesbians and others who resisted the Nazi societal pressures. One survivor called it a place of "slow extermination" where one could be worked to death or simply have the will to live taken away bit by bit, until they faded away. ${ }^{32}$ Even within the camp, a place filled with people who did not fit the Nazi mould, lesbians doubly marginalized and were severely punished for any sexual involvement; such encounters could result in isolation in the prison block or severe physical discipline. ${ }^{33}$ Gender roles were more flexible in this place, but still strict. Women were employed as guards, but all supervisors were male Nazi officials. ${ }^{34}$ Work details assigned to prisoners reinforced gender roles, with women sewing, mending, cooking and performing other household tasks unless assigned to harsh details of shoveling sand or other manual labour. ${ }^{35}$ Pregnant women who were non-Aryan were often killed or their infants were killed, but women who were Aryan and in the camp for political or criminal reasons would have their babies put up for adoption by good German families, reinforcing population policies and furthering the goal of a strong race. ${ }^{36}$

26. Helm, 2014, xvii.

27. Ibid, xviii \& 92 .

28. Spurlin, 2009, 57.

29. Helm, 2014, 25.

30. Schoppmann, 1996, 21.

31. Ibid., 31.

32. Helm, 2014, xxii.

33. Ibid, 94.

34. Ibid, 30.

35. Ibid, 12.

36. Ibid, 27. 
Lesbian prisoners might also be assigned to men's camp brothels in order to cure them of their sexuality, as Nazi's felt women were often "seduced" into homosexuality and could be "educable." 37 This idea of reforming sexuality went beyond the experience of Ravensbrück prisoners. Male homosexual prisoners at Buchenwald received hormone implants and other medical experiments in attempts to eliminate their homosexuality. ${ }^{38}$ At Bützow camp, an entire block of lesbians were kept separate from other prisoners and "the SS guards set the interned Russian and French prisoners on the imprisoned lesbians and told them to 'fuck them up good and proper."'139 Nazi ideology perverted gender relations so extensively that even sexual assault was seen as a viable 'cure' for deviant sexuality.

The National Socialist regime had significant consequences for lesbian women. Not only were many killed in concentration camps, either for their "asocial" sexuality or for reasons of race, or political affiliation, but a great many suffered while denying their sexuality publically as a shield against persecution. Those who chose to remain openly homosexual faced severe consequences including: "resistance, confrontation, pressure from the family," and loss of occupation. ${ }^{40}$ After the war, prejudice against lesbians and others categorized as 'asocials' in general persisted; not one black triangle survivor was called upon to give evidence at the initial Hamburg War Crimes trials, nor at any later trials. ${ }^{{ }^{11}}$ No black triangle bearers received financial compensation from the German government, and no outside aid from Western Allies was designated for affected men or women. ${ }^{42}$

The actions of the Nazis show consistently that, throughout their time in power, women were a problem to the regime. For the same reasons that lesbians were targeted for intimidation, oppression, and incarceration, "more Jewish women were deported and killed than Jewish men." ${ }^{43}$ Women who did not fit the Aryan stereotype were a threat to National Socialism. Because women carried the unique power of motherhood, they could either rebuild or destroy the nation. Just as Jewish women were deported or imprisoned to annihilate their population, lesbian women were targeted for failing to contribute as mothers and wives.

William Spurlin, in his work on homosexuality and National Socialism, shows that one of the tragedies of the lesbian experience during the war is how little of it is remembered. He argues that because lesbian women frequently chose to disguise themselves to avoid persecution, historians are now faced with a lack of archival documentation. In the absence of sources, some are left "to assume that lesbians were more or less invisible under National Socialism and suffered little feared or actual persecution. ${ }^{144}$ The irony of this is that the persecution which caused the erasure of identities leads many to believe lesbians were not persecuted. This is simply untrue. While "the masquerade...helped diminish the social visibility of lesbians under National Socialism," their experiences and sufferings are still valid and need to be addressed. ${ }^{45}$ Spurlin believes that by examining these experiences through a gendered lens, a careful historian can "help to open up spaces of lesbian existence within Holocaust scholarship.."16

Lesbian lives during the Nazi regime in Germany need to be understood not only through the National Socialist ideologies and policies that affected so many others, but also through a specific understanding of gender. Assigned gender roles were a foundational component of the Nazi worldview and policy structure, and anyone who deviated from performing those roles was considered a threat to the norm. Lesbian women faced prejudice, imprisonment, and oppression not only from the Nazis, but also from ordinary Germans, due to the culture of fear of difference that the Nazis perpetuated. By looking at lesbianism as a divergence from traditional women's roles as mothers and wives, it becomes clear how the Nazis perceived and punished nonconforming women. While they did not establish legal sanctions against lesbians, the Nazis nevertheless made these women feel unsafe for being themselves and forced many into hiding, into false marriages, and into concentration camps, taking away some or all of their autonomy. Allowing the experiences of these women to continue going unnoticed would be akin to being complicit with the goals of the National Socialist regime. Instead, studying their experiences makes them clearly visible and acknowledges and respects their existence and their experiences of victimization. Once we recall that lesbian women in Nazi Germany were targeted for both their gender and their sexuality and acknowledge their dual oppression, we can begin to refocus their integral experiences in the narrative of Nazi Germany. It is only by acknowledging this dual oppression that their importance in the story can be properly established.

44. Ibid.

45. Ibid, 56.

46. Ibid, 48.

37. Schoppmann, 1996, 10.

38. Cant, 2012, 240.

39. Spurlin 2009, 60.

40. Schoppmann 1996, 80.

41. Helm 2014, 90.

42. Ibid.

University of Saskatchewan Undergraduate Research Journal 


\section{Bibliography}

Cant, Bob. "'Anyone who thinks of homosexual love is our enemy' - remembering the experiences of lesbian gay, bisexual and transgender people during the Nazi terror." Diversity and Equality in Health Care 9. 2012: 239-241.

Helm, Sarah. Ravensbrück: Life and Death in Hitler's Concentration Camp for Women. Penguin Random House, New York, NY: 2014.

Lybeck, Marti M. Desiring Emancipation: New Women and Homosexuality in Germany, 1890-1933. SUNY Press, New York, NY: 2014.
Marhoefer, Laurie. "Lesbianism, Transvestitism, and the Nazi State: A Microhistory of a Gestapo Investigation, 1939-1943." American Historical Review 121:4. 2016.

Schoppmann, Claudia. Days of Masquerade: Life Stories of Lesbians During the Third Reich. Translated by Allison Brown. Columbia University Press, New York, NY: 1996.

Spurlin, William J. Lost Intimacies: Rethinking Homosexuality under National Socialism. Peter Lang, New York, NY: 2009 . 
Lesbians under National Socialism (Crowder)

University of Saskatchewan Undergraduate Research Journal 